University of Montana

ScholarWorks at University of Montana

8-2006

\title{
Disturbance Facilitates Invasion: The Effects are Stronger Abroad than at Home
}

José L. Hierro

Diego Villarreal

Özkan Eren

Jon M. Graham

Ragan M. Callaway

University of Montana - Missoula, Ray.Callaway@mso.umt.edu

Follow this and additional works at: https://scholarworks.umt.edu/biosci_pubs

Part of the Biology Commons

Let us know how access to this document benefits you.

\section{Recommended Citation}

Hierro, José L.; Villarreal, Diego; Eren, Özkan; Graham, Jon M.; and Callaway, Ragan M., "Disturbance Facilitates Invasion: The Effects are Stronger Abroad than at Home" (2006). Biological Sciences Faculty Publications. 211.

https://scholarworks.umt.edu/biosci_pubs/211

This Article is brought to you for free and open access by the Biological Sciences at ScholarWorks at University of Montana. It has been accepted for inclusion in Biological Sciences Faculty Publications by an authorized administrator of ScholarWorks at University of Montana. For more information, please contact scholarworks@mso.umt.edu. 


\title{
Disturbance Facilitates Invasion: The Effects Are Stronger Abroad than at Home
}

\author{
José L. Hierro, ${ }^{1,2, *}$ Diego Villarreal, ${ }^{2, \dagger}$ Özkan Eren, ${ }^{3, \$}$ Jon M. Graham, ${ }^{4, \S}$ and Ragan M. Callaway ${ }^{1, \|}$
}

1. Division of Biological Sciences, University of Montana, Missoula, Montana 59812;

2. Facultad de Ciencias Exactas y Naturales, Universidad Nacional de La Pampa, (6300) Santa Rosa, La Pampa, Argentina;

3. Adnan Menderes Üniversitesi, Fen-Edebiyat Fakültesi, Biyoloji Bölümü, 09010 Aydin, Turkey;

4. Department of Mathematical Sciences, University of Montana, Missoula, Montana 59812

Submitted November 5, 2005; Accepted April 26, 2006; Electronically published July 10, 2006

Online enhancements: appendixes.

ABSTRACT: Disturbance is one of the most important factors promoting exotic invasion. However, if disturbance per se is sufficient to explain exotic success, then "invasion" abroad should not differ from "colonization" at home. Comparisons of the effects of disturbance on organisms in their native and introduced ranges are crucial to elucidate whether this is the case; however, such comparisons have not been conducted. We investigated the effects of disturbance on the success of Eurasian native Centaurea solstitialis in two invaded regions, California and Argentina, and one native region, Turkey, by conducting field experiments consisting of simulating different disturbances and adding locally collected C. solstitialis seeds. We also tested differences among C. solstitialis genotypes in these three regions and the effects of local soil microbes on C. solstitialis performance in greenhouse experiments. Disturbance increased C. solstitialis abundance and performance far more in nonnative ranges than in the native range, but $C$. solstitialis biomass and fecundity were similar among populations from all regions grown under common conditions. Eurasian soil microbes suppressed growth of C. solstitialis plants, while Californian and Argentinean soil biota did not. We suggest that escape from soil pathogens may contribute to the disproportionately powerful effect of disturbance in introduced regions.

\footnotetext{
* E-mail: joselhierro@yahoo.com.

† E-mail: dvillarreal@exactas.unlpam.edu.ar.

₹ E-mail: ozkaneren@adu.edu.tr.

${ }^{\S}$ E-mail: jgraham@mso.umt.edu.

" E-mail: ray.callaway@mso.umt.edu.
}

Am. Nat. 2006. Vol. 168, pp. 144-156. () 2006 by The University of Chicago. 0003-0147/2006/16802-41408\$15.00. All rights reserved.
Keywords: biological invasions, Centaurea solstitialis, community invasibility, disturbance, invasive plants, ruderals.

In contemporary biological invasions, humans assist other organisms to overcome one of the most limiting of ecological factors, dispersal (Eriksson and Ehrlén 1992; Tilman 1997; Seabloom et al. 2003). Once dispersed, however, introduced individuals (exotics) may face different limitations to their abundance and distribution than in their communities of origin. Understanding these differences may help to explain the unusual success of some species as exotics (Darwin 1859; Elton 1958; Blossey and Nötzold 1995; Callaway and Aschehoug 2000). Comparative ecological studies of invasive species where they are native versus where they are exotic are thus essential to this understanding. Also, analyzing the relative importance of factors influencing invasive organisms over large geographical scales may yield unique insight into ecological and evolutionary theory (Callaway et al. 2005; Hierro et al. 2005; Sax et al. 2005). Most research on invasion biology, however, has been conducted only in nonnative ranges and has not incorporated the biotic and abiotic conditions that affect exotics at home (Hierro et al. 2005).

Disturbance commonly enhances the abundance and distribution of exotic plants (Gray 1879; Elton 1958; D'Antonio et al. 1999). The positive role of disturbance in some plant invasions appears to help many newcomers to establish nearly monospecific stands (e.g., Maddox and Mayfield 1985; Whisenant 1990). However, research on the role of disturbance in invasions has followed the trend of research in invasion biology in general. There are many observational (see D'Antonio et al. 1999 for a comprehensive review) and experimental studies (e.g., Hobbs and Atkins 1988; Burke and Grime 1996; Leishman and Thomson 2005) linking disturbance to exotic success in introduced regions, but we know very little about how disturbance affects exotics in their native range. Specifically, we do not know whether disturbance triggers the same spectacular response in the abundance of invaders where they are natives as where they are exotics.

Given the ruderal life history of many exotic plants, it 
is not surprising that they flourish in disturbed habitats (Baker 1974; Grime 1974). Proposed general mechanisms by which disturbance promotes invasions include reduction of competitive pressure from other plants, stimulation of germination, and alteration of resource levels (D'Antonio et al. 1999), all of which favor the ruderal strategy. If the success of exotics in disturbed places is due to their ruderal nature and these mechanisms are sufficient to explain why exotics thrive under such conditions, then exotics should respond similarly to disturbance where they are native. In other words, we do not know whether invasion abroad is different from colonization at home (see Thompson et al. 1995; Davis et al. 2001; Grime 2001). Invasion may not differ from colonization; alternatively, disturbance may operate in association with other proposed mechanisms for exotic plant success (i.e., enemy release, empty niches, evolutionary change, novel weapons) and cause species to attain community dominance only where they occur as exotics. The effect of disturbance on invasion is not limited to the direct responses of exotic species. The success of an invader can also be influenced by the response of resident native species to disturbance, which can depend on the familiarity of a community with a particular disturbance regime (D'Antonio et al. 1999). Indeed, as early as 1879 , Gray speculated that exotics dominate in disturbed areas because they are adapted to disturbances that are novel to the locals.

We used an explicitly biogeographic approach to investigate the response of an annual plant, Centaurea solstitialis L., Asteraceae (yellow starthistle; see app. A in the online edition of the American Naturalist for a review of the biology and introduction history of this species), to disturbance in its native and nonnative range. We pursued this objective by conducting the same disturbance and seed addition experiments in one region of origin, southern Turkey, and two regions in the introduced range of $C$. solstitialis that vary considerably in climate and the dominant plant functional group, northern California and central Argentina. We also conducted greenhouse experiments to evaluate regional genotypic differences in C. solstitialis and the effects of local soil microbes.

In its native range, C. solstitialis is largely confined to disturbed sites and is considered a typical ruderal species (Davis 1975; Uygur et al. 2004). In both California and central Argentina, C. solstitialis is one of the most abundant invasive exotic species (Pitcairn et al. 1998; J. L. Hierro and D. Villarreal, unpublished data), and although its occurrence is also often associated with disturbed areas (Maddox et al. 1985; J. L. Hierro and D. Villarreal, unpublished data), the role of disturbance in its invasion success has received surprisingly little attention (but see Dukes 2002; Gelbard and Harrison 2005). Here we focus on four fundamental questions: Does the response of $C$. solstitialis to disturbance vary between its native and introduced ranges? Do C. solstitialis populations exhibit genetically based differences in size and fecundity among studied regions? Does the effect of soil biota on C. solstitialis growth vary among these regions? Is the response to disturbance consistent for two climatically and ecologically contrasting regions where $C$. solstitialis has been introduced?

\section{Material and Methods Study Sites}

Field experiments were conducted in northern California, central Argentina, and southern Turkey (see app. B in the online edition of the American Naturalist for locations). Table 1 displays information on climate, soil, and vegetation at the experimental sites in the three regions. A $5 \% \mathrm{HCl}$ test indicated that soils at all sites are noncalcareous. Vegetation at the California site was dominated by Eurasian annual grasses and herbs, such as Bromus diandrus, Bromus hordeaceus, Hordeum murinum, Lolium multiflorum, and Trifolium hirtum. In sharp contrast, the site in central Argentina was dominated by native perennial bunchgrasses, including Pitptochaetium napostense, Poa ligularis, Stipa clarazii, and Stipa tenuissima, accompanied by subordinate annual and perennial herbs such as Gnaphalium gaudichaudianum and Baccharis sp. In Turkey, the site was grassland dominated by one native perennial species, Hordeum bulbosum, and less important annual and perennial species, including Avena barbata, Bromus squarrous, Trifolium sp., and Cichorium intybus. Sites in California and central Argentina historically have been grazed but never plowed. The site in Turkey has also been grazed and used for wheat and barley production without the addition of fertilizers. Cropping ceased 4 years before our study. In northern California, fire occurred every 25 years before European settlement and every $\sim 8$ years after the arrival of Europeans (McCreary 2004). During most of the twentieth century, fire frequency dramatically decreased as the result of active fire suppression. Fire is most likely to occur in summer and early fall in this region. In central Argentina, Medina et al. (2000) reported mean fire intervals of $\sim 13$ years for 1787-1879, 15 years for 1880-1910, and $\sim 7$ years for 1911-1993, with summer as the main fire season. Near our experimental site in Turkey, the fire frequency interval for the period 1820-1960 has been estimated at about 9 years, with high-intensity fires occurring every $\sim 25$ years (Neyisci 1985). Summer is also the main fire season in southern Turkey. 
Table 1: Characteristics of experimental sites in California, Argentina, and Turkey

\begin{tabular}{lccc}
\hline Characteristics & California & Central Argentina & Turkey \\
\hline Mean annual precipitation $(\mathrm{mm})$ & $749^{\mathrm{a}}$ & 686 & $527^{\mathrm{b}}$ \\
Mean annual temperature $\left({ }^{\circ} \mathrm{C}\right)$ & 17 & 15 & 14 \\
$\quad$ Maximum $\left({ }^{\circ} \mathrm{C}\right)$ & 24 & 22 & 22 \\
$\quad$ Minimum $\left({ }^{\circ} \mathrm{C}\right)$ & 10 & 8 & 6 \\
Soil texture $(\%)$ & 50 sand, 12 clay, 38 silt & 70 sand, 2 clay, 28 silt & 58 sand, 20 clay, 22 silt \\
Soil total N and C (\%) & $.38 \mathrm{~N}, 4.56 \mathrm{C}$ & $.16 \mathrm{~N}, 1.62 \mathrm{C}$ & $.20 \mathrm{~N}, 2.34 \mathrm{C}$ \\
Soil pH & 5.85 & 7.68 & 7.29 \\
Soil depth $(\mathrm{m})$ & $>1.00$ & $>1.00$ & .60 \\
Bare ground $(\%)$ & 3 & 1.5 & 16 \\
Litter $(\%)$ & 45 & 14 & 7 \\
Annual grasses $(\%)$ & 50 & $<1$ & 11 \\
Annual herbs $(\%)$ & 2 & 12 & 2 \\
Perennial grasses $(\%)$ & 0 & 64 & 53 \\
Perennial herbs $(\%)$ & 0 & 8 & 11
\end{tabular}

Note: Data on soil particle size distribution and chemistry are means of five soil samples collected from the top $10 \mathrm{~cm}$. Soil depths are also means of five measures. Percent cover of bare ground, litter, and plants are means of $151 \times 1$-m plots, obtained in fall 2002 in California and Argentina and fall 2003 in Turkey.

a October to May, Mediterranean.

b October to June, Mediterranean.

\section{Disturbance and Seed Addition Experiments}

Experiment 1. In January 2002 in central Argentina, August 2002 in California, and July 2003 in Turkey, we selected a representative natural grassland that had no Centaurea solstitialis but, based on the abundance of the weed nearby, would apparently be ideal for $C$. solstitialis if it dispersed there. We selected sites located in open and flat fields, so that light availability and slope were as comparable as possible across regions. Selected sites were isolated by at least $5 \mathrm{~km}$ from other populations of this plant and main roads to minimize potential influences of the seed bank. Study sites in all regions were fenced to prevent damage from domestic animals. Logistic constraints related to carrying out field experiments at such global scale and concerns about spreading a noxious weed into uninvaded grasslands limited our ability to replicate sites within each region. We took care to follow the same protocol in all three regions. In March 2002 in Argentina, October 2002 in California, and September 2003 in Turkey, we marked $601 \times 1-\mathrm{m}$ experimental plots that were separated from each other by $0.50 \mathrm{~m}$. Vegetation in the space between plots was mowed at the beginning of the experiment and periodically throughout the study.

At each site, plots were randomly selected to form four groups of 15, and each group received one of the following four treatments: soil turnover, to represent plowing; fire; clipping, to represent haying or vertebrate herbivory; and no disturbance. Soil turnover was performed with a shovel to a depth of $0.30 \mathrm{~m}$, mixing vegetation and litter. For the fire treatment, a fire was started in a corner of the plot and allowed to burn inside a metal frame $1 \times 1 \mathrm{~m}$ wide $\times 0.30 \mathrm{~m}$ tall; in all cases, fire completely burned the material present in the plots. For the clipping treatment, vegetation was clipped once to a height of $1 \mathrm{~cm}$ and removed from plots. In the $15 \mathrm{un}$ disturbed plots, we recorded percent cover of plant species, bare ground, and litter to estimate initial conditions at each study site (table 1). Once treatments were established, and before the arrival of autumn rains in California and Turkey, we added 200 locally collected pappus achenes (hereafter referred to as seeds) of C. solstitialis to the $0.50 \times 0.50-\mathrm{m}$ area in the center of each experimental plot, which allowed for a buffer zone. We used only seeds that looked healthy and filled with an embryo (see Gerlach and Rice 2003 for details on the protocol we followed). To keep seeds from being moved out of the plots, we placed $0.50 \times 0.50 \mathrm{~m}$ wide $\times 0.15 \mathrm{~m}$ tall wood frames around the seeded center of plots. Frames were removed shortly after the first rains, which occurred 2, 16, and 26 days after adding seeds in Argentina, California, and Turkey, respectively. At the end of each season, we counted the number of $C$. solstitialis individuals present in the 180 experimental plots, with the exception of the late fall census in 2002 in California. Centaurea solstitialis densities were calculated per square meter. At the peak of flowering, during the summer following the addition of seeds (January 2003, August 2003, and August 2004 in Argentina, California, and Turkey, respectively), we determined levels of invasion/colonization in all plots as proportion of plant establishment (number of plants present in plots in the summer divided by the number of seeds added to plots in the fall), height, and 
number of flower heads of $C$. solstitialis. To estimate plant fecundity, we counted the number of inflorescences of five randomly selected individuals in each experimental plot and took the mean of these plants as the number of flower heads per plant in each plot. When the number of plants was less than five, we counted inflorescences of all individuals present in the plot and average them to obtain the number of inflorescences per plant. In addition, we estimated the percent cover of plant species, bare ground, and litter in all experimental plots.

Experiment 2. This experiment was conducted for a second time in the nonnative regions from autumn 2003 to summer 2004. Experimental plots were located $5 \mathrm{~m}$ away from the first year's plots. The experimental protocol was identical to that in experiment 1 (see app. $\mathrm{C}$ in the online edition of the American Naturalist).

\section{Common Garden Experiment}

Because we used local seed sources in our field experiments, we assessed the potential for differences in genotype among C. solstitialis populations in California, Argentina, and the native range to explain our biogeographic comparisons by conducting a common garden experiment in a greenhouse on the University of Montana campus. We used seeds from six C. solstitialis populations in California, six populations in central Argentina, five populations in Turkey, and five populations in Georgia, near Turkey, and also within the native range of this plant (see app. D in the online edition of the American Naturalist for locations). Seeds were collected in January 2002 in Argentina, August 2002 in California, and August 2004 in Turkey and Georgia. For each population, we planted five seeds in each of five $2,500-\mathrm{cm}^{3}$ plastic pots. Seedlings in pots were then thinned to one individual and watered periodically to field capacity throughout the experiment. Pots were filled with a mixture of 2 parts sand and 1 part soil. Soil was collected from a grassland site located near Missoula, Montana. The sand was 20/30 grit, corresponding to mean diameters of $0.85 \mathrm{~mm}$ and $0.60 \mathrm{~mm}$, respectively. At senescence ( $\sim 8$ months of growth), we counted the number of flower heads produced by each individual, harvested plants, dried them at $60^{\circ} \mathrm{C}$ until constant weight, and determined total biomass.

\section{Soil Biota Experiment}

We also examined whether soil microbes in native and introduced regions had differential effects on C. solstitialis growth. We collected soils from two sites in California, three sites in Argentina, and five sites in Eurasia (see app. B for locations). After collection, soils were immediately subjected to slow air-drying to mimic drying conditions that would occur during natural drought. One-half of the soils were then treated by triple autoclaving on three successive days to kill soil microbes. Pure sterile and nonsterile soils were used to plant three C. solstitialis seeds, collected from a single population in Turkey (population 13 in app. D), in each of two to $10250-\mathrm{mL}$ pots per site-soil treatment combination. Seedlings in pots were soon thinned to one individual. Single C. solstitialis plants were grown for 53 days while being fertilized once every 2 weeks with $10 \mathrm{~mL}$ $0.34 \mathrm{~g} / \mathrm{L}$ solution of Miracle Grow Professional (15N-2P$20 \mathrm{~K})$ fertilizer and watered to field capacity every $2-3$ days. Fertilization was intended to neutralize potential differences in nutrient flushes among sites caused by the sterilization of soil. At the end of the experiment, plants were harvested, dried at $60^{\circ} \mathrm{C}$, and weighed for total biomass.

\section{Plant Density in Naturally Occurring Populations}

We measured plant density in naturally occurring populations of C. solstitialis in three disturbed sites in summer 2003 and 2004 in each of the three regions to evaluate whether levels of invasion and colonization in experimental plots matched general abundances in the regions where we worked and to compensate for the lack of replicated experiments within a region. At each site, plant density was determined in five $1 \times 1$-m plots. Sites in all three regions have a long history of natural and prescribed fire and domestic grazing. In Turkey, two of the sites had been used for agricultural purposes in the past. In all cases, sites were located within the general region where disturbance and seed addition experiments were conducted (see app. B for locations). Two sites in Turkey (sites 1 and 2 in app. B) were destroyed by vandals and flooding in the winter of 2004; thus, density in summer 2004 was measured only at one site.

\section{Precipitation during the Study}

Total rainfall in the 2002-2003 season in California (785 $\mathrm{mm})$ and in 2002 in central Argentina $(748 \mathrm{~mm}$ ) was slightly above the annual mean for both regions (749 and $686 \mathrm{~mm}$, respectively). In contrast, 2003-2004 was drier than average in California $(658 \mathrm{~mm})$, but more importantly, 99\% of the rainfall occurred between October and March, resulting in considerable drought during the late spring and summer. Similarly, rainfall in 2003 in Argentina was only $378 \mathrm{~mm}$, the fifth driest year since 1911. Precipitation in the 2002-2003 season in Turkey $(550 \mathrm{~mm})$ was close to the mean value (527 mm), but in 2003-2004, precipitation was almost twice the average $(926 \mathrm{~mm})$. 


\section{Statistical Analyses}

We compared seasonal changes in C. solstitialis densities through the year among regions for individual treatments with repeated-measures ANOVA and Tukey post hoc comparisons. Due to the lack of data for late fall census in California, analyses were conducted with data from late winter, late spring, and summer. Data were transformed with the square root function to meet assumptions of this statistical test. Data for C. solstitialis's proportional establishment, patch height, and number of inflorescences per plant in the summers following seed additions were analyzed using a randomized complete block design, where regions were treated as blocks. In this design, both region and disturbance treatments were considered fixed factors. Pairwise comparisons between disturbance treatments within a single region and those between regions for a single disturbance treatment were performed using Tukey's method. We used a square root transformation for proportional establishment and patch height data and a logarithmic transformation for fecundity data to meet ANOVA assumptions and improve the distribution of residuals. Percent cover of $C$. solstitialis versus that of all other plant species present in plots in the summer following seed additions were analyzed using paired-sample $t$-tests. Data from the common garden experiment were analyzed with two-way ANOVA with region of origin as fixed factor and population nested within region. Centaurea solstitialis biomass in the soil biota experiment was analyzed with three-way ANOVA, where soil origin and soil treatment were treated as fixed factors and site was nested within soil origin. We transformed data with the square root function to meet ANOVA assumptions and improve the distribution of residuals. Finally, we assessed differences in plant density of naturally occurring populations of $C$. solstitialis among all three regions using nested ANOVA, where site was nested within region, with post hoc comparisons again performed using Tukey tests.

\section{Results}

\section{Disturbance and Seed Addition Experiments}

As expected, disturbance enhanced the abundance and performance of Centaurea solstitialis plants in all three regions, but the effects of disturbance were greater in the nonnative ranges than in the native range. Soil turnover and fire in California and soil turnover in Argentina were the treatments where the weed experienced its greatest success (figs. 1-3).

Seasonal changes in plant density during the year. In plots with soil disturbance, the density of $C$. solstitialis was consistently more than one order of magnitude higher in the nonnative sites than in the native site (fig. 1). Interestingly, C. solstitialis density continued to increase through the spring months in both invaded regions, indicating extended germination, but this did not occur in Turkey, where plant density remained almost unchanged during the experimental period. Density in the fire treatment was higher in California than in the other regions. As in the soil turnover treatment, we observed a second wave of germination in this treatment in the spring in the nonnative regions, but it was much stronger in California than in Argentina. Differences in plant density among regions were smaller in the clipping and control treatments than those in the other two treatments; however, C. solstitialis density was still higher in introduced than in native regions.

Plant proportional establishment. The proportion of $C$. solstitialis seeds that established plants in the summer in the soil disturbance treatment was about 20 times greater in nonnative than in native regions (fig. $2 A$ ). Plant establishment in the fire treatment was much higher in California than in the other two regions, but in the clipping and control treatments, establishment was greater in the other introduced region, Argentina, than in California and Turkey. Relative to the control, all three disturbance treatments significantly increased C. solstitialis establishment in California; in contrast, only soil turnover in Argentina and fire in Turkey had such effects.

Patch height. Centaurea solstitialis plants in soil turnover and fire treatments were much taller in introduced than in native sites (fig. $2 B$ ). In the clipping treatment, plants were taller only in Argentina than at home, and height was similar in all three regions in plots without disturbance. Plants in California and Argentina were significantly taller in plots with soil disturbance and fire than in control plots, but in Turkey, disturbance had no effect on plant height.

Plant fecundity. Fire was the only disturbance treatment where $C$. solstitialis produced significantly more flowers abroad than at home (fig. 2C). In the controls, flower production was higher only in Argentina than at home.

Plant cover. By the summer following the initiation of experiment 1, C. solstitialis had formed virtual monocultures only in introduced regions (fig. 3). In the soil disturbance treatment, the cover of $C$. solstitialis was more than $80 \%$ in California and Argentina, but at home, the cover of this plant did not differ from the cover of all other plant species combined. California was the only nonnative region where fire promoted the establishment of near monocultures of $C$. solstitialis; in sharp contrast, in Turkey, the cover of other species in this treatment was significantly higher than the cover of our target species. In the clipping and control treatments, the percent cover 


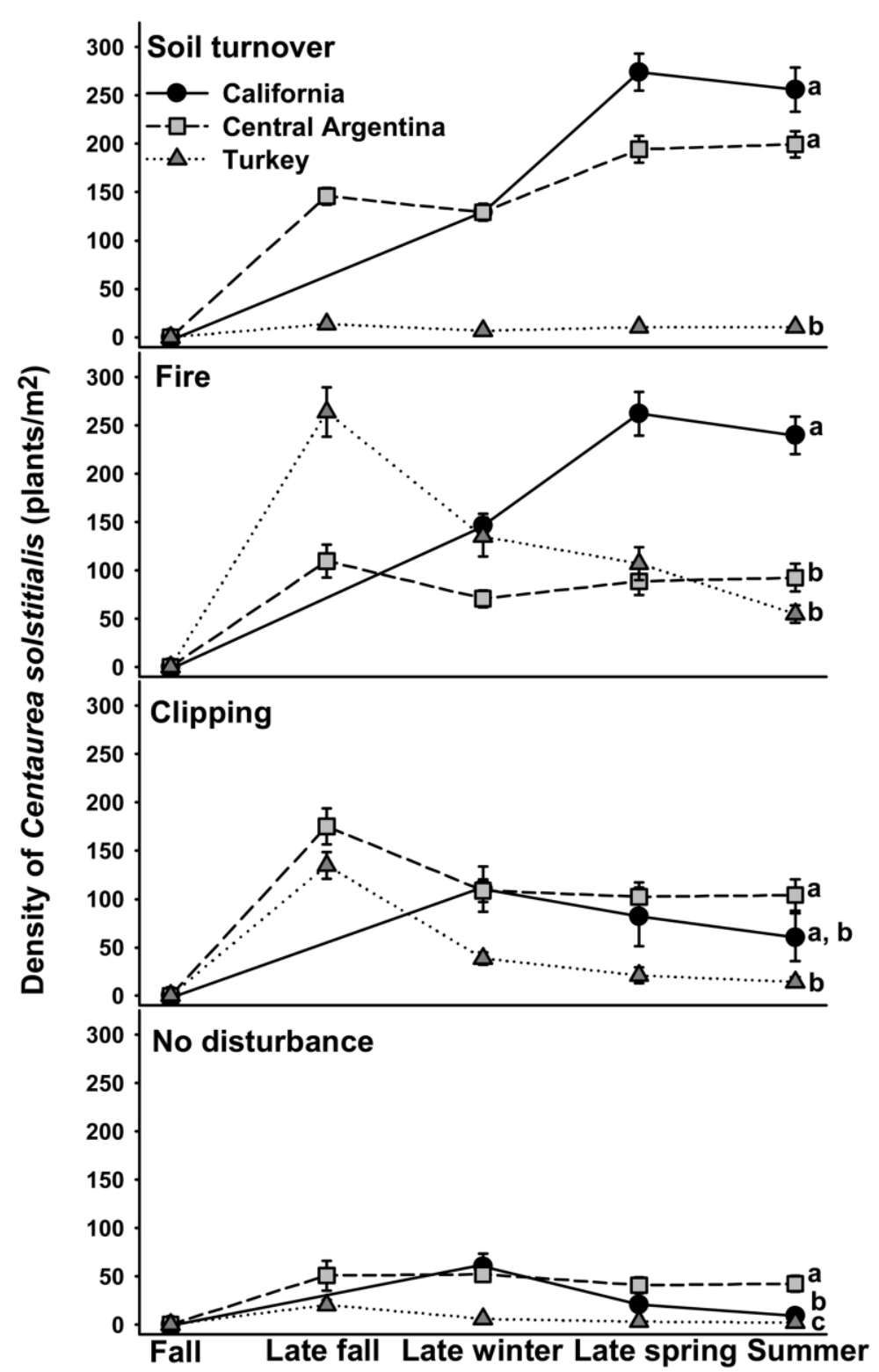

Figure 1: Seasonal changes in Centaurea solstitialis density during the year for each treatment in its introduced (California and central Argentina) and native (Turkey) ranges in disturbance and seed addition experiment 1. Data are means \pm 1 SE. Data from late fall census in California were not available; for this reason, repeated-measures ANOVAs were conducted with data from late winter, late spring, and summer (soil turnover: $F_{\text {region }}=200.70$, $\mathrm{df}=2,42, \quad P<.001 ; \quad F_{\text {season }}=55.38, \quad \mathrm{df}=2,41, \quad P<.001 ; \quad F_{\text {region } \times \text { season }}=12.30, \quad \mathrm{df}=4,82, \quad P<.001 ;$ fire: $\quad F_{\text {region }}=19.76, \quad \mathrm{df}=2,42, \quad P<.001 ;$ $F_{\text {season }}=19.57, \mathrm{df}=2,41, P<.001 ; F_{\text {region } \times \text { season }}=21.71, \mathrm{df}=4,82, P<.001 ;$ clipping: $F_{\text {region }}=7.98, \mathrm{df}=2,42, P<.001 ; F_{\text {season }}=33.11, \mathrm{df}=$ $2,41, P<.001 ; F_{\text {region } \times \text { season }}=5.73, \mathrm{df}=4,82, P<.001 ;$ no disturbance: $F_{\text {region }}=21.00, \mathrm{df}=2,42, P<.001 ; F_{\text {season }}=19.12, \mathrm{df}=2,41, P<.001$; $\left.F_{\text {region } \times \text { season }}=6.41, \mathrm{df}=4,82, P<.001\right)$. Different letters indicate significant differences $(P<.05)$ between regions, as determined by Tukey tests.

of other species was higher than the cover of C. solstitialis in all three regions, with the exception of clipping in Argentina. Results from experiment 2 confirmed in general the effects of disturbance on C. solstitialis in invaded regions (see app. C).

\section{Common Garden Experiment}

Total C. solstitialis biomass and inflorescence number did not differ $(F=1.26, \mathrm{df}=2,19, P=.31$, and $F=2.91$, $\mathrm{df}=2,19, \quad P=.08$, respectively) among populations 

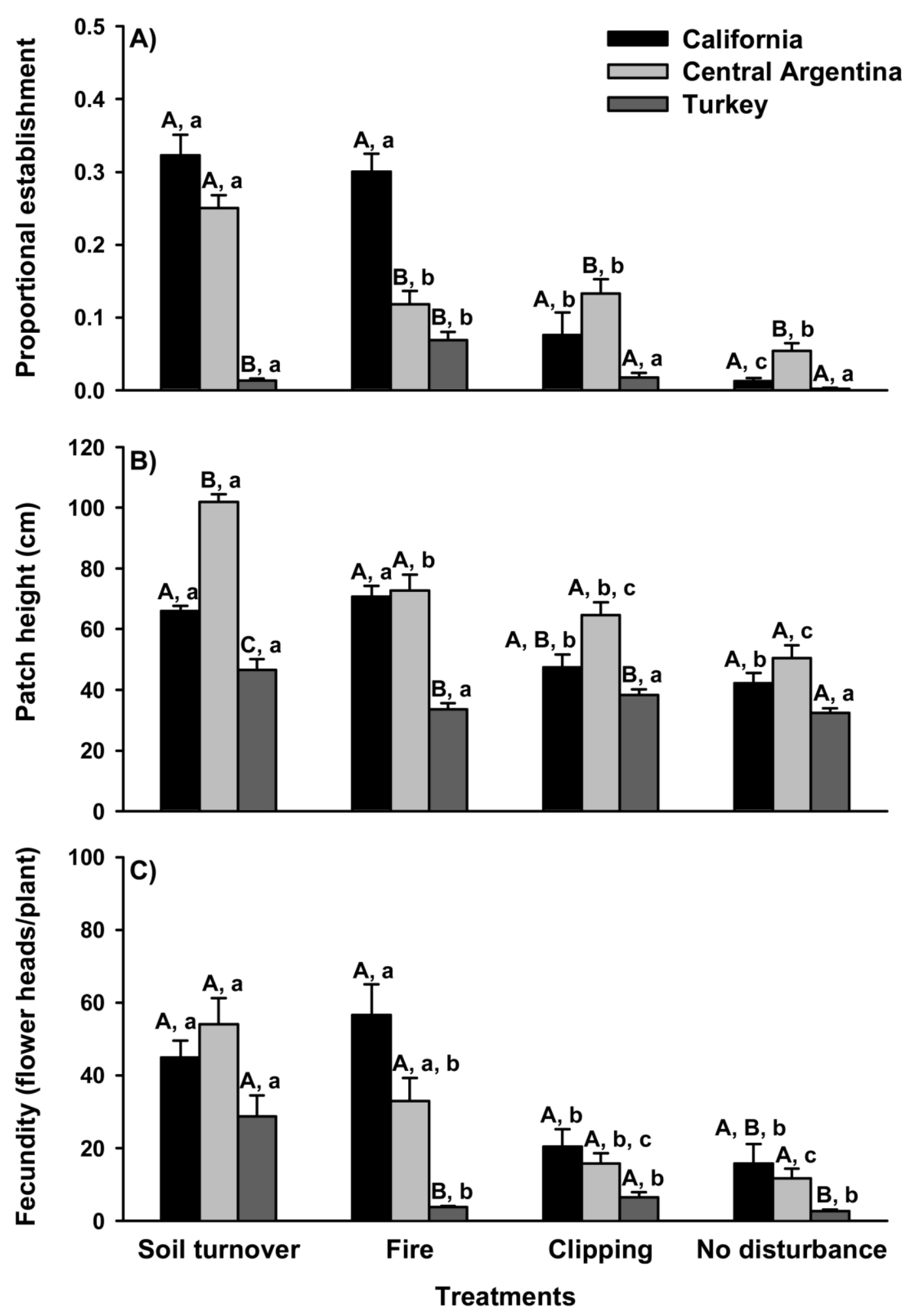

Figure 2: Proportional establishment $(A)$, size $(B)$, and fecundity $(C)$ of Centaurea solstitialis in its introduced (California and central Argentina) and native (Turkey) ranges, at the end of disturbance and seed addition experiment 1 (proportional establishment: $F_{\text {region }}=90.84, \mathrm{df}=2,168$, $P<.001 ; F_{\text {disturbance treatment }}=73.33, \mathrm{df}=3,168, P<.001 ; F_{\text {region } \times \text { treatment }}=19.20, \mathrm{df}=6,168, P<.001 ;$ patch height: $F_{\text {region }}=79.04, \mathrm{df}=2,136$, $P<.001 ; F_{\text {disturbance treatment }}=28.57, \mathrm{df}=3,136, P<.001 ; F_{\text {region } \times \text { treatment }}=6.34, \mathrm{df}=6,136, P<.001 ;$ fecundity: $F_{\text {region }}=43.19, \mathrm{df}=2,136, P<$ $\left..001 ; F_{\text {disturbance treatment }}=38.52, \mathrm{df}=3,136, P<.001 ; F_{\text {region } \times \text { treatment }}=5.84, \mathrm{df}=6,136, P<.001\right)$. Data are means $+1 \mathrm{SE}$. Bars with different uppercase letters indicate significant differences $(P<.05)$ between regions for a single disturbance treatment, and those with different lowercase letters indicate significant differences between disturbance treatments within a single region, according to Tukey tests. 


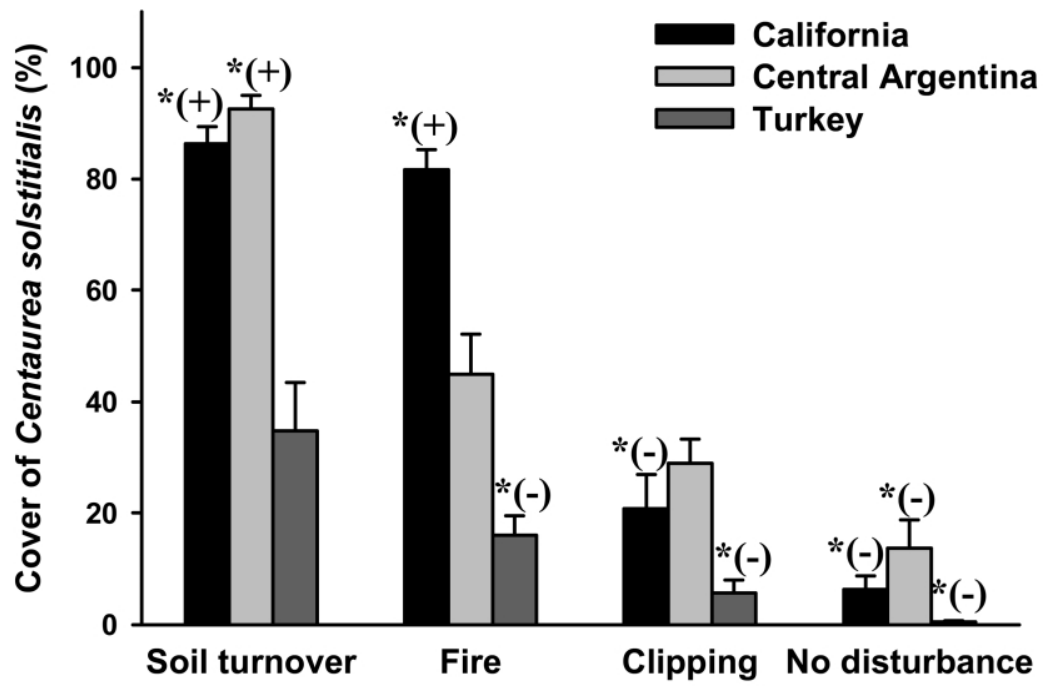

Figure 3: Cover of Centaurea solstitialis in experimental plots in introduced (California and central Argentina) and native (Turkey) ranges at the end of disturbance and seed addition experiment 1. Data are means +1 SE. Asterisks above bars indicate significant differences $(P<.05)$ between the cover of $C$. solstitialis and that of all other plant species combined as indicated by paired-sample $t$-tests (soil turnover: $t=-12.50, \mathrm{df}=14$, $P<.001 ; t=-35.70, \mathrm{df}=14, P<.001 ;$ and $t=0.33, \mathrm{df}=14, P=.75 ;$ fire: $t=-9.20, \mathrm{df}=14, P<.001 ; t=-1.04, \mathrm{df}=14, P=.32 ;$ and $t=9.41, \mathrm{df}=14, P<.001 ;$ clipping: $t=4.68 \mathrm{df}=14, P<.001 ; t=1.11, \mathrm{df}=14, P=.29 ;$ and $t=17.57, \mathrm{df}=14, P<.001 ;$ no disturbance: $t=24.06, \mathrm{df}=14, P<.001 ; t=4.88, \mathrm{df}=14, P<.001 ;$ and $t=77.67, \mathrm{df}=14, P<.001$ for California, Argentina, and Turkey, respectively). Higher cover of $C$. solstitialis than of all other species is indicated by a plus sign in parentheses; a minus sign indicates the inverse relationship between these groups.

from California (biomass, $1.23 \pm 0.07 \mathrm{~g}$; flower heads, $7.67 \pm 0.53$ ), central Argentina (biomass, $1.28 \pm 0.09 \mathrm{~g}$; flower heads, $8.07 \pm 0.40$ ), and Eurasia (biomass, $1.04 \pm 0.07 \mathrm{~g}$; flower heads, $6.32 \pm 0.29)$.

\section{Soil Biota Experiment}

Sterilization of native Eurasian soils caused a $75 \%$ increase in the total biomass of C. solstitialis. In contrast, sterilization had no significant effects on individuals growing in Californian and Argentinean soils (fig. 4).

\section{Plant Density in Naturally Occurring Populations}

The density of C. solstitialis in naturally occurring populations in summer 2003 was around four to five times higher in the invaded regions than in the native region (fig. 5). After the dry spring of 2004 in California and the exceptionally dry year of 2003 in Argentina, C. solstitialis densities were similar among all regions. Importantly, densities in the summer following the very wet year in Turkey (2003-2004) were still three to four times less than those following a normal rainfall year in California (2002-2003) and Argentina (2002).

\section{Discussion}

Does the Response of Centaurea solstitialis to Disturbance Vary between Its Native and Introduced Ranges?

Perhaps the most accepted truism in invasion biology is that disturbance promotes exotic invasion (Gray 1879; Elton 1958; D’Antonio et al. 1999). Our results support this perspective but indicate that disturbance may have stronger effects in the nonnative ranges of $C$. solstitialis than in its native range (figs. 1, 2). This finding questions the assumption that disturbance per se is sufficient to explain the remarkable success of invasive plant species (and specifically C. solstitialis) in disturbed conditions in their nonnative ranges. If our findings are general, then the common and powerful effects of disturbance must act in concert with other factors, allowing certain species to attain community dominance only where they occur as exotics (fig. 3). Of the factors investigated here, escape from soil pathogens may contribute to this pattern (fig. 4).

Our experiments were not conducted at many sites within each region; therefore, our results must be interpreted with caution until they are confirmed or rejected by spatially replicated experiments within regions. However, our experimental field evidence was corroborated by our descriptive measures of $C$. solstitialis density (fig. 5) and our general field observations 


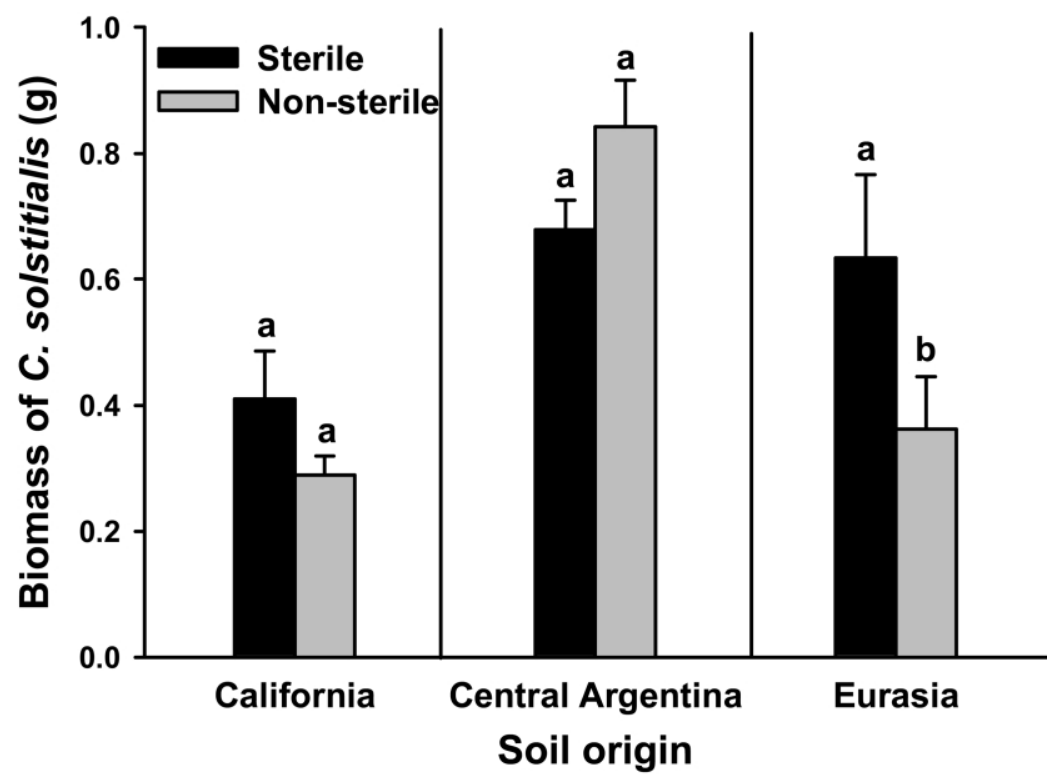

Figure 4: Total biomass of Centaurea solstitialis grown in sterilized and nonsterilized soils collected from two introduced regions, California and central Argentina, and the native range, Eurasia $\left(F_{\text {soil origin }}=0.74, \mathrm{df}=2,7, \quad P=.51 ; \quad F_{\text {sterilization treatment }}=2.12, \quad \mathrm{df}=1,107, \quad P=.15\right.$; $\left.F_{\text {origin } \times \text { treatment }}=6.76, \mathrm{df}=2,107, P=.002\right)$. Data are means +1 SE. Different letters indicate significant differences $(P<.05)$ between sterilization treatments for each region, as indicated by Tukey tests.

in disturbed areas in California, Argentina, and Turkey. In many disturbed areas in California and Argentina, we have observed near monocultures of C. solstitialis, but we have never seen monocultures in Turkey or the Georgian Caucasus, also within the native range of the weed.

\section{Do C. solstitialis Populations Exhibit Genetically Based Differences in Size and Fecundity among Studied Regions?}

Plants grown from seeds collected from many populations in the three study regions and under common conditions were not different in size or fecundity. Therefore, we found no evidence that the contrasting responses of $C$. solstitialis to disturbance at home and abroad were due to genetic differences in these traits between native and introduced populations (see Blossey and Nötzold 1995; Lee 2002; Maron et al. 2004; Bossdorf et al. 2005).

\section{Does the Effect of Soil Biota on C. solstitialis Growth Vary among Studied Regions?}

Recent studies have demonstrated the importance of belowground pathogens in exotic plant invasions (Klironomos 2002; Callaway et al. 2004; Reinhart and Callaway 2004, forthcoming). Stronger suppressive effects of Eur- asian soil biota on C. solstitialis growth (fig. 4) provide an initial indication that this plant may have escaped soil pathogens at home. As in other studies, however, our work examined the effects of soil microbes on individual plant performance; we do not know whether they can affect population dynamics and generate the contrasting numerical abundances between native and nonnative regions that we document here. Moreover, in an experiment investigating feedback interactions between $C$. solstitialis and the microbial community that develops around its roots (J. L. Hierro and R. M. Callaway, unpublished data), we found no biogeographical differences in feedback loops as demonstrated for another exotic Centaurea (Callaway et al. 2004). In addition, it is unclear whether soil microbes would affect $C$. solstitialis in the way detected in our greenhouse study in the presence of other plant species. In sum, our results are far from being conclusive, and potential biogeographic differences in the effects of soil biota on $C$. solstitialis need further exploration.

\section{Other Mechanisms}

Several other mechanisms not investigated here may interact with disturbance to drive greater success in introduced ranges, including the release in nonnative regions from aboveground specialist herbivores and pathogens and soil microfauna that control plant population growth in 


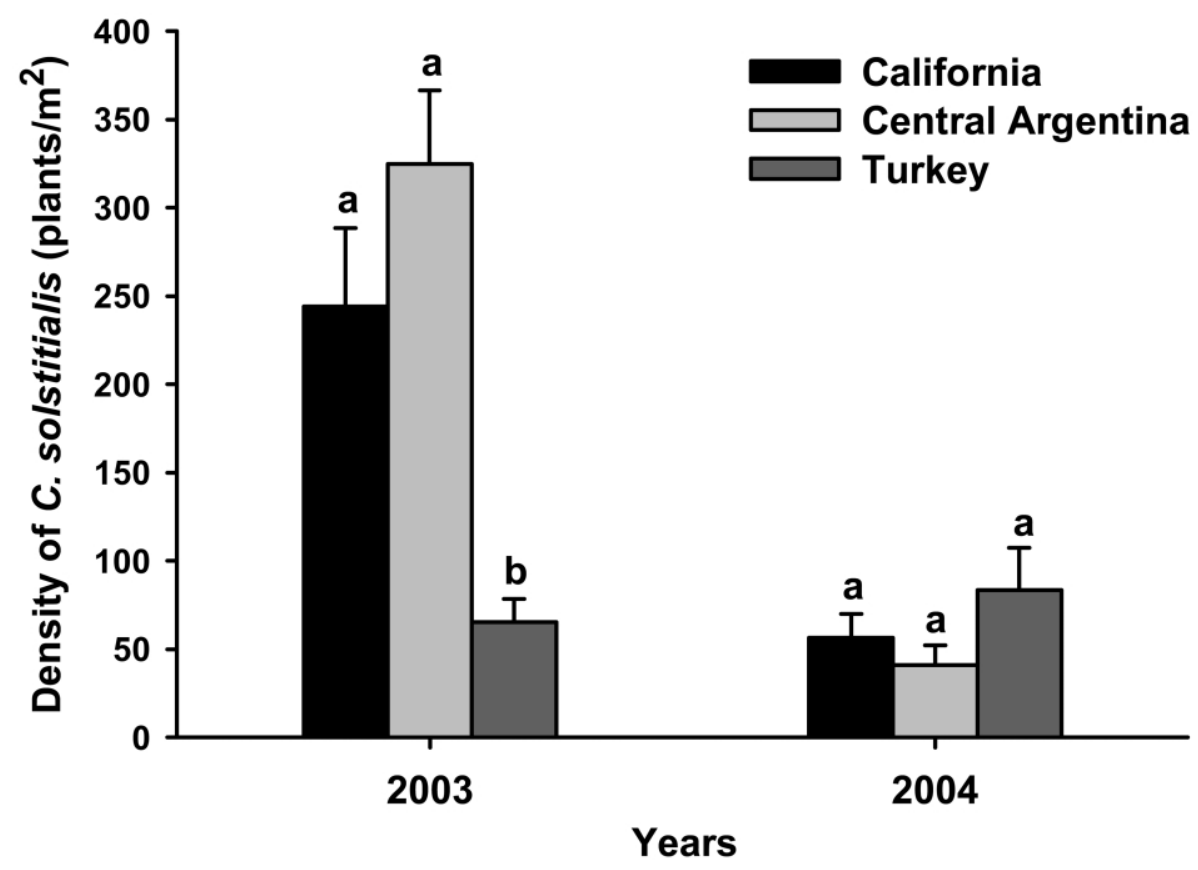

Figure 5: Density of Centaurea solstitialis in naturally occurring populations in summer in introduced (California and central Argentina) and native (Turkey) ranges (2003: $F=9.90, \mathrm{df}=2,6, P=.01 ; 2004: F=1.10, \mathrm{df}=2,4, P=.42$ ). Data are means +1 SE. Different letters indicate significant differences $(P<.05)$ among regions for each year, as indicated by Tukey tests.

native locales (see Elton 1958; DeWalt et al. 2004). The fact that our experiment assessed invasion/colonization levels after the addition of the same number of seeds in each region and throughout a single annual cycle rules out the possibility that capitula seed predators, the most commonly selected insects for biological control, are responsible for invasion success. If the absence of natural enemies is the comechanism, then enemies that attack seeds in the soil, seedlings, or rosettes must be involved. In fact, Uygur (2004; see also app. A) reported the presence of root-boring weevils (Ceratapion spp.) in seedlings and rosettes of C. solstitialis in southern Turkey. Late fall seedling densities in fire and clipped treatments that were higher in Turkey than in central Argentina (late fall census is not available for California; fig. 1), however, suggest that seed and seedling mortality was not greater at home than abroad. Marked declines during the rosette stage (winter months; fig. 1) in these treatments in Turkey, on the other hand, may have been due to the effect of consumers. We saw no evidence of aboveground herbivory in the field. Similarly, we did not observe signs of seed, seedling, or rosette consumption or obvious aboveground infections in the soil disturbance treatment in Turkey, where recruitment was exceedingly low and almost indistinguishable from that in plots without disturbance throughout the duration of the experiment (fig. 1). Additionally, it is unclear why enemies would have stronger negative effects on plants in the soil disturbance treatment than in any other disturbance treatment at home. The decline in plant density observed in our experiments in Turkey corresponds with general declines observed during the rosette and flowering stages reported by Uygur and colleagues (2004) in other regions of Turkey. However, they also did not know the causes of the decline. If the natural enemies hypothesis applies at all to the invasion success of C. solstitialis, an important implication of our work is that enemies must have their effects very early in plant development.

Variation in the response of resident vegetation to disturbance is another factor that could have caused the greater success of $C$. solstitialis in introduced ranges than in its native range. Perhaps other members of the plant communities in Turkey, in particular those of the ruderal community, are able to colonize disturbed areas more rapidly than members of the ruderal community in the introduced regions, creating conditions of greater competition in native than in invaded communities. In fact, in the late fall sampling in Turkey (fig. 1), it was difficult to identify C. solstitialis seedlings because of the presence of a dense cover of other members of the Asteraceae family that looked similar to juvenile individuals of our target species in a number of disturbed plots. Additionally, the 
cover of other plant species in Turkey was significantly higher than the cover of C. solstitialis in all treatments in the summer with the exception of soil disturbance, where percent cover of these two groups was similar (fig. 3). In contrast, C. solstitialis formed near-monocultures in soildisturbance plots in both recipient communities and in burned plots in California (fig. 3). In combination, these results support to some extent the idea that differences in the resilience of the plant community could have affected the response of $C$. solstitialis to disturbance in each of the studied regions. Similarly, the remarkable success of $C$. solstitialis, primarily in terms of density and percent cover (figs. 2A, 3, C2A), in burned plots in California relative to the other two regions, could be related to variation in the response to fire of the vegetation present in each locality. That is, given the widespread dominance of annual species in California, fire in autumn can kill seeds and individuals, creating favorable conditions for invasion that could last longer than in Turkey and Argentina, where dominant perennial grasses (table 1) can resprout and rapidly resume competition against newcomers. Additionally, percent cover of litter was greater in the Californian site than in the Argentinean and Turkish sites (table 1), which could have resulted in higher fire intensity in our treatment in California.

A hypothesis similar to that described in the previous paragraph was proposed by Asa Gray over 120 years ago. Gray (1879) thought that exotic plants may thrive in disturbed areas because they are adapted to disturbances that are novel to the locals. Since the "locals" in California are represented almost exclusively by exotics from Eurasia, in our study, this hypothesis might better apply to central Argentina, where grasslands are dominated by native bunchgrasses (table 1). Moreover, a recent study showed that the present dominance of exotic annual grasses themselves in California grasslands may be due to disturbance (Corbin and D'Antonio 2004). Although the simulation of a novel disturbance such as plowing in Argentina promoted C. solstitialis abundance and performance more than any other treatment when compared with Turkey and other treatments in Argentina (figs. 2, 3), the success of the weed was greater in this nonnative region than at home in virtually every disturbance type, including natural disturbance such as fire (fig. 2B, 2C). Perhaps a longer history with humans and, in consequence, with severe disturbance enables this plant to gain tenure over natives under a large suite of disturbance types. However, proportional establishment and fecundity were higher in Argentina than in Turkey, even in the absence of disturbance (fig. 2), reinforcing the idea that other factors in addition to disturbance promote greater success in nonnative relative to origin ranges.

The observation that C. solstitialis can form dense and almost monospecific stands in recipient regions has prompted some researchers to propose that allelopathy could be behind its invasion success (e.g., Maddox et al. 1985), and there is good evidence that allelopathy may play a role in plant invasions (Hierro and Callaway 2003), including invasion by other Centaurea species (Bais et al. 2003; Vivanco et al. 2004). However, recent experiments coordinated in three different laboratories have not found convincing evidence that C. solstitialis is allelopathic (R. M. Callaway, S. Strauss, J. M. Vivanco, and J. Yoder, unpublished data), suggesting that the novel-weapons hypothesis (Callaway and Aschehoug 2000; Callaway and Ridenour 2004) is unlikely to explain the disproportional success of this species in nonnative ranges.

Although soils were relatively deep in all three experimental sites (table 1), shallower soils in the native site could have influenced the outcome of our study as soil depth can reduce resource partitioning and increase competition between C. solstitialis and other plants (Sheley and Larson 1995; Dukes 2001, 2002). Centaurea solstitialis recruitment in the soil disturbance treatment at home, however, was low even in the first three months after we initiated our field experiment (fig. 1), a period of time likely to be too short for soil depth to become a factor. Differences in soil depth between native and nonnative regions could have been involved, on the other hand, in the declines in plant density observed in the other treatments. Due to the lack of true replication of our field experiment, we cannot rule out a possible role of soil depth in our biogeographical pattern; however, the results from the disturbance and seed addition experiment are consistent with measurements of density obtained in natural C. solstitialis populations in disturbed sites in the three regions (fig. 5). Our measurements in Turkey appear to be quite conservative for $C$. solstitialis abundance in general because a different study describes densities about one order of magnitude lower at all measured sites in this country (Uygur et al. 2004). Thus, it is highly unlikely that we simply chose places to work in Turkey where C. solstitialis performs poorly. Densities of C. solstitialis in California in the summer of 2003, on the other hand, were comparable with those at three other sites studied over 7 years (Pitcairn et al. 2002), indicating that densities we recorded in 2004 are exceptionally low for this region and were due to the dry spring season of that year. Adequate or high rainfall in the spring appears to greatly increase the abundance of $C$. solstitialis in California. There are no previous measurements of density in Argentina for comparison with our densities; however, the extreme drought conditions during the year before our 2004 measurements suggest that the 2003 densities are more representative. 
Is the Response to Disturbance Consistent for Two Climatically and Ecologically Contrasting Regions where C. solstitialis Has Been Introduced?

Limited establishment in plots without disturbance in California (figs. 1-3, C1, C2) highlights the important role of disturbance for C. solstitialis invasion (also see Dukes 2002; Gerlach and Rice 2003; Gelbard and Harrison 2005). The importance of disturbance, especially soil turnover, for $C$. solstitialis to attain community dominance is also clear in central Argentina (figs. 1-3, C1, C2). In contrast to the strong context specificity of invasions found by others (e.g., D'Antonio 1993; Lambrinos 2002), and despite substantial variation in rainfall patterns and dominant plant functional groups between California and Argentina, we found that disturbance to plant communities in both regions prompted invasion and domination by $C$. solstitialis in a very similar manner. The better response of C. solstitialis to disturbance abroad than at home, however, indicates that disturbance is only part of the answer for why this species is such a dominant invader. Whether the efficient exploitation of disturbed sites by $C$. solstitialis in California and central Argentina shares a mechanistic commonality remains to be determined.

\section{Acknowledgments}

We thank M. Pitcairn for assistance in locating field sites; the Zapico, Berhongaray, and Torroba-Hevia families for letting us use their land; the Sierra Foothill Research and Extension Center (SFREC) crew, J. Díaz, E. Estanga, A. Fajardo, M. Narváez, A. Parras, D. Procopio, A. Villarreal, D. Villarreal, M. Villarreal, and students from the University of La Pampa (UNLPam) for their help in the field; C. Hall for assistance in the greenhouse; and C. Lortie and J. Maron for discussion. Funding was provided by grants from the National Science Foundation (NSF), the USDA, the US Department of Defense Strategic Environmental Research and Development Program, and the Civilian Research and Development Foundation to R.M.C. and grants from the NSF Doctoral Dissertation Improvement Grant program, SFREC-University of California, Davis, and the UNLPam to J.L.H.

\section{Literature Cited}

Bais, H. P., R. Vepachedu, S. Gilroy, R. M. Callaway, and J. M. Vivanco. 2003. Allelopathy and exotic plants: from genes to invasion. Science 301:1377-1380.

Baker, H. G. 1974. The evolution of weeds. Annual Review of Ecology and Systematics 5:1-24.

Blossey, B., and R. Nötzold. 1995. Evolution of increased competitive ability in invasive non-indigenous plants: a hypothesis. Journal of Ecology 83:887-889.

Bossdorf, O., H. Auge, L. Lafuma, W. E. Rogers, E. Siemann, and
D. Prati. 2005. Phenotypic and genetic differentiation between native and introduced plant populations. Oecologia (Berlin) 144: $1-11$.

Burke, M. J. W., and J. P. Grime. 1996. An experimental study of plant community invasibility. Ecology 77:776-790.

Callaway, R. M., and E. T. Aschehoug. 2000. Invasive plants versus their new and old neighbors: a mechanism for exotic invasion. Science 290:521-523.

Callaway, R. M., and W. M. Ridenour. 2004. Novel weapons: a biochemically based hypothesis for invasive success and the evolution of increased competitive ability. Frontiers in Ecology and the Environment 2:436-433.

Callaway, R. M., G. Thelen, A. Rodriguez, and W. E. Holben. 2004. Release from inhibitory soil biota in Europe and positive plantsoil feedbacks in North America promote invasion. Nature 427: 731-733.

Callaway, R. M., J. L. Hierro, and A. S. Thorpe. 2005. Evolutionary trajectories in plant and soil microbial communities. Pages 341363 in D. F. Sax, J. J. Stachowicz, and S. D. Gaines, eds. Species invasions: insights into ecology, evolution, and biogeography. Sinauer, Sunderland, MA.

Corbin, J. D., and C. M. D'Antonio. 2004. Competition between native perennial and exotic annual grasses: implications for an historical invasion. Ecology 85:1273-1283.

D’Antonio, C. 1993. Mechanisms controlling invasion of coastal plant communities by the alien succulent Carpobrotus edulis. Ecology 74:83-95.

D’Antonio, C. M., T. L. Dudley, and M. Mack. 1999. Disturbance and biological invasions: direct effects and feedbacks. Pages 413452 in L. R. Walker, ed. Ecosystems of disturbed ground. Elsevier, Amsterdam.

Darwin, C. 1859. The origin of species by means of natural selection. J. Murray, London.

Davis, M. A., K. Thompson, and J. P. Grime. 2001. Charles S. Elton and the dissociation of invasion ecology from the rest of ecology. Diversity and Distribution 7:97-102.

Davis, P. H., ed. 1975. Flora of Turkey and the east Aegean Islands. Vol. 5. Edinburgh Press, Edinburgh.

DeWalt, S. J., J. S. Denslow, and K. Ickes. 2004. Natural-enemy release facilitates habitat expansion of the invasive tropical shrub Clidemia hirta. Ecology 85:471-483.

Dukes J. S. 2001. Biodiversity and invasibility in grassland microcosms. Oecologia (Berlin) 126:563-568.

- 2002. Species composition and diversity affect grassland susceptibility and response to invasion. Ecological Applications 12: 602-617.

Elton, C. S. 1958. The ecology of invasions by animals and plants. Methuen, London.

Eriksson, O., and J. Ehrlén. 1992. Seed and microsite limitation of recruitment in plant populations. Oecologia (Berlin) 91:360-364.

Gelbard, J. L., and S. Harrison. 2005. Invasibility of roadless grasslands: an experimental study of yellow starthistle. Ecological Applications 15:1570-1580.

Gerlach, J. D., and K. J. Rice. 2003. Testing life history correlates of invasiveness using congeneric plant species. Ecological Applications 13:167-179.

Gray, A. 1879. The predominance and pertinacity of weeds. American Journal of Science and Arts 118:161-167.

Grime, J. P. 1974. Vegetation classification by reference to strategies. Nature 250:26-31. 
2001. Plant strategies, vegetation processes, and ecosystem properties. 2nd ed. Wiley, New York.

Hierro, J. L., and R. M. Callaway. 2003. Allelopathy and exotic plant invasion. Plant and Soil 256:29-39.

Hierro, J. L., J. M. Maron, and R. M. Callaway. 2005. A biogeographic approach to plant invasions: the importance of studying exotics in their introduced and native range. Journal of Ecology 93:5-15.

Hobbs, R. J., and L. Atkins. 1988. Effect of disturbance and nutrient addition on native and introduced annuals in plant communities in the Western Australia wheatbelt. Australian Journal of Ecology 13:171-179.

Klironomos, J. 2002. Feedback with soil biota contributes to plant rarity and invasiveness in communities. Nature 417:67-70.

Lambrinos, J. G. 2002. The variable invasive success of Cortaderia species in a complex landscape. Ecology 83:518-529.

Lee, C. E. 2002. Evolutionary genetics of invasive species. Trends in Ecology \& Evolution 17:386-391.

Leishman, M. R., and V. P. Thomson. 2005. Experimental evidence for the effects of additional water, nutrients and physical disturbance on invasive plants in low fertility Hawkesbury Sandstone soils, Sydney, Australia. Journal of Ecology 93:38-49.

Maddox, D. M., and A. Mayfield. 1985. Yellow starthistle infestations are on increase. California Agriculture 39:10-12.

Maddox, D. M., A. Mayfield, and N. H. Poritz. 1985. Distribution of yellow starthistle (Centaurea solstitialis) and Russian knapweed (Centaurea repens). Weed Science 33:315-327.

Maron, J. L., M. Vilà, R. Bommarco, S. Elmendorf, and P. Beardsley. 2004. Rapid evolution of an invasive plant. Ecological Monographs 74:261-280.

McCreary, D. D. 2004. Fire in California's oak woodlands: a white paper of the University of California. Integrated Hardwood Range Management Program, Berkeley.

Medina, A. A., E. G. Dussart, H. D. Estelrich, and E. A. Morici. 2000. Reconstrucción de la historia del fuego en un bosque de Prosopis caldenia (Burk.) de Arizona, sur de la provincia de San Luis. Multequina 9:91-98.

Neyisci, T. 1985. Antalya-Doyran yöresi kizilçam Pinus brutia Ten. Ormanlarinda Yanginlarin Tarihsel Etkileri. Ormancilik Arastirma Enstitüsü Yayinlari, Teknik Raporlar Serisi 29:67-91. [In Turkish.]

Pitcairn, M. J., R. A. O'Connell, and J. M. Gendron. 1998. Yellow starthistle: survey of statewide distribution. Pages 64-66 in D. M. Woods, ed. Biological control program annual summary, 1997. California Department of Food and Agriculture, Plant Health and Pest Preservation Services, Sacramento.

Pitcairn, M. J., D. M. Woods, D. B. Joley, and V. Popescu. 2002.
Seven-year population buildup and combined impact of biological control insects on yellow starthistle. Pages 57-59 in D. M. Woods, ed. Biological control program annual summary, 2001. California Department of Food and Agriculture, Plant Health and Pest Preservation Services, Sacramento.

Reinhart, K. O., and R. M. Callaway. 2004. Soil biota facilitate exotic Acer invasions in Europe and North America. Ecological Applications 14:1737-1745.

2006. Soil biota and invasive plants. New Phytologist 170 445-457.

Sax, D. F., J. H. Brown, E. P. White, and S. D. Gaines. 2005. Species dynamics of invasions: insights into the mechanisms that limit species diversity. Pages 447-465 in D. F. Sax, J. J. Stachowicz, and S. D. Gaines, eds. Species invasions: insights into ecology, evolution, and biogeography. Sinauer, Sunderland, MA.

Seabloom, E. W., W. S. Harpole, O. J. Reichman, and D. Tilman. 2003. Invasion, competitive, dominance, and resource use by exotic and native California grassland species. Proceedings of the National Academy of Sciences of the USA 100:13384-13389.

Sheley, R. L., and L. L. Larson. 1994. Observation: comparative life history of cheatgrass and yellow starthistle. Journal of Range Management 47:450-456.

. 1995. Interference between cheatgrass and yellow starthistle at 3 soil depths. Journal of Range Management 48:392-397.

Thompson, K., J. G. Hodgson, and T. C. G. Rich. 1995. Native and alien invasive plants: more of the same? Ecography 18:390-402.

Tilman, D. 1997. Community invasibility, recruitment limitation, and grassland biodiversity. Ecology 78:81-92.

Uygur, S. 2004. Density of Centaurea solstitialis L. and its natural enemies Ceratapion spp. in southern Turkey. Turkish Journal of Agriculture and Forestry 28:333-339.

Uygur, S., L. Smith, F. N. Uygur, M. Cristofano, and J. Balciunas. 2004. Population densities of yellow starthistle (Centaurea solstitialis) in Turkey. Weed Science 52:746-753.

Vivanco, J. M., H. P. Bais, F. R. Stermitz, G. C. Thelen, and R. M. Callaway. 2004. Biogeographical variation in community response to root allelochemistry: novel weapons and exotic invasion. Ecology Letters 7:285-292.

Whisenant, S. G. 1990. Changing fire frequencies on Idaho's Snake River Plain: ecological and management implications. USDA Forest Service, Intermountain Research Station, General Technical Report INT-276.

Associate Editor: George W. Gilchrist Editor: Donald L. DeAngelis 